\title{
Analysis of Diversity in Pythium aphanidermatum Populations from a Single Greenhouse Reveals Phenotypic and Genotypic Changes over 2006 to 2011
}

\author{
A. M. Al-Sadi, A. G. Al-Ghaithi, Z. M. Al-Balushi, and A. H. Al-Jabri, Department of Crop Sciences, Sultan Qaboos University, Al
} Khod 123, Sultanate of Oman

\begin{abstract}
Al-Sadi, A. M., Al-Ghaithi, A. G., Al-Balushi, Z. M., and Al-Jabri, A. H. 2012. Analysis of diversity in Pythium aphanidermatum populations from a single greenhouse reveals phenotypic and genotypic changes over 2006 to 2011. Plant Dis. 96:852-858.

A study was conducted to investigate phenotypic and genotypic changes within Pythium aphanidermatum populations during the period 2006 to 2011. In total, 92 isolates of $P$. aphanidermatum (59 in 2006 and 33 in 2011) were obtained from different planting sites (soil) of cucumber from a single greenhouse. Generated sequences of the internal transcribed spacer (ITS) ribosomal DNA showed that all, except one isolate, share an identical sequence of the ITS region. Most (89\%) P. aphanidermatum isolates were found to be aggressive on cucumber seedlings, with no significant differences in the aggressiveness level between populations obtained from different planting rows or different years. Sensitivity to metalaxyl among populations of $P$. aphanidermatum increased significantly from concentration resulting in $50 \%$ growth inhibition levels of 0.070 to 1.823 (average $0.824 \mu \mathrm{g}$ $\mathrm{ml}^{-1}$ ) in 2006 to 0.002 to 0.564 (average $0.160 \mu \mathrm{g} \mathrm{ml}^{-1}$ ) in 2011 . Amplified fragment length polymorphism analysis of the 92 isolates

nidermatum populations from 2006 and 2011 were found to have low levels of genetic diversity $(H=0.1425)$, which implies introduction of the isolates into the greenhouse via common sources. Results from analysis of molecular variance $\left(\mathrm{F}_{\mathrm{ST}}=0.0307\right.$ in 2006 and 0.0222 in 2011) provided evidence for frequent exchange of Pythium inoculum between different planting locations within the same year. However, the analysis showed moderate levels $\left(\mathrm{F}_{\mathrm{ST}}=0.1731\right)$ of genetic differentiation among populations from the 2 years. This was supported by unweighted pair group method with arithmetic means analysis, which showed clustering of many of the 2006 isolates in separate clusters. The change in the metalaxyl sensitivity of the populations from 2006 to 2011 accompanied by the genetic differences among these two populations may suggest that many of the isolates from 2006 were lost and were replaced by new and highly sensitive $P$. aphanidermatum isolates by 2011 .
\end{abstract} produced 92 different genotypes and 985 polymorphic loci. P. apha-
Cucumber (Cucumis sativus) is an important crop in different parts of the world. Cucumber together with gherkins are among the top five vegetable crops in production worldwide, with a total production of over 60 million metric tons in 2009 (13). In Oman, cucumber is the most important vegetable crop in greenhouses and occupies over $95 \%$ of the national greenhouses. Most cucumber cultivation is soil based and most growers use greenhouses exclusively for cucumber production, with three to four cropping cycles per year.

Damping-off and vine decline diseases are considered the biotic factors most limiting to cucumber production in Oman. Losses up to $50 \%$ of seedlings and mature plants were reported to occur $(3,4)$. Severity of the diseases was found to increase under stress, especially in greenhouses which are affected by irrigation water salinity (1).

Pythium spp. are among the pathogens most frequently associated with damping-off and vine decline diseases in Oman and elsewhere $(3,4,18,31)$. Among the different Pythium spp. associated with damping-off and vine decline, Pythium aphanidermatum is the most widely distributed species in greenhouses in Oman and is the most aggressive (3).

Pythium spp. can be introduced into greenhouses via different sources, including soil used for cucumber cultivation, as well as irrigation water, tools, and potting media $(2,7,33)$. This results in a buildup of Pythium inoculum in greenhouse soils which, in turn, increases disease. Among many of the control options for Pythium spp., metalaxyl (mefenoxam) fungicides are among the most com-

Corresponding author: A. M. Al-Sadi, E-mail: alsadi@squ.edu.om

Accepted for publication 27 December 2011.

http://dx.doi.org/10.1094/PDIS-07-11-0624

(C) 2012 The American Phytopathological Society monly used fungicides for management of Pythium spp.-induced diseases $(6,9,24)$. Despite frequent use of metalaxyl fungicides in Oman, no resistance has been reported to the fungicide among Pythium populations $(5,6,8)$.

Few studies have addressed genetic diversity in populations of $P$. aphanidermatum infecting cucumber and other crops in different countries $(5,8,14,20)$ and there is a lack of knowledge concerning population structure of $P$. aphanidermatum populations infecting cucumber in a single greenhouse. No previous studies have been conducted in Oman or elsewhere to investigate changes over time in the aggressiveness, metalaxyl sensitivity, and genetic diversity in $P$. aphanidermatum populations from a single greenhouse. Such studies would help in predicting the effects of cultivation practices and continuous use of certain fungicides on population dynamics of pathogens. The main objective of this study was to characterize changes in aggressiveness, metalaxyl sensitivity, and genetic diversity in $P$. aphanidermatum populations from a single greenhouse during 2006 to 2011. Specific objectives were to (i) study phylogenetic relationships among $P$. aphanidermatum isolates from 2006 and 2011, (ii) test for changes in the level of aggressiveness of $P$. aphanidermatum populations following 17 monocropping cycles of cucumber from 2006 to 2011, (iii) test for changes in metalaxyl sensitivity of $P$. aphanidermatum populations following 26 applications of metalaxyl fungicide from 2006 to 2011, (iv) investigate whether $P$. aphanidermatum populations from a single greenhouse consist of a single or multiple genotypes, and (v) investigate change in the population genetic structure of $P$. aphanidermatum populations from 2006 to 2011. Investigations into these areas could identify changes that occur in $P$. aphanidermatum populations during cultivation cycles and following fungicide applications.

\section{Materials and Methods}

Site of the study. A single greenhouse selected for the study, located in Barka 40, km north of Muscat, was established for cucumber cultivation in 2005. From January 2005 to March 2011, the 
greenhouse was used for cucumber cultivation for 20 consecutive cycles, at a rate of 3 cycles per year. There was usually a fallow period of 10 to 20 days between cycles, extended up to 40 days in summer. When used for cucumber cultivation, the temperature was usually 18 to $32^{\circ} \mathrm{C}$. However, temperatures above $50^{\circ} \mathrm{C}$ can occur during the summer fallow period. Over 31 different metalaxyl applications at a rate of metalaxyl at approximately $28 \mathrm{mg}$ a.i. per seedling were used between 2005 and 2011. The greenhouse soil consisted of 91 to $93 \%$ sand and the farmers did not replace soil in the greenhouse since they started using it for cucumber cultivation. The greenhouse has 12 different planting rows, spaced at a distance of approximately 50 to $70 \mathrm{~cm}$. Each planting row has approximately 75 planting spots, with $50-\mathrm{cm}$ intrarow spacing between plants. Before each cropping cycle, animal manure at approximately 1 to $1.5 \mathrm{~kg} / \mathrm{m}^{2}$ was incorporated into the soil. This was followed by application of N-P-K and foliar fertilizers at the locally recommend rate (Q. Al-Maawali, Ministry of Agriculture and Fisheries, Oman, personal communication).

Collection of samples. Two separate collections of soil samples were conducted at the greenhouse. The first was in March 2006, where 375 different soil samples were collected from planting rows 1 through 5. Before transplanting cucumber seedlings into greenhouses, approximately $50-\mathrm{g}$ soil samples were collected from the top 5 to $10 \mathrm{~cm}$ of soil, where the cucumber seedlings were to be transplanted. The soil samples were labeled and kept in separate plastic bags. In March 2011, 300 soil samples were collected from rows $1,3,5$, and 6 .

Isolation and identification of Pythium spp. Isolation of Pythium spp. from soil samples was done within 15 days of soil collection. About $100 \mathrm{mg}$ of air-dried soil was spread on the surface of $1.7 \%$ corn meal agar (CMA; Oxoid, England) amended with pimaricin at $5 \mu \mathrm{g} \mathrm{ml}^{-1}$, rifampicin at $10 \mu \mathrm{g} \mathrm{ml}^{-1}$, ampicillin at $200 \mu \mathrm{g} \mathrm{ml}^{-1}$, pentachloronitrobenzene (19) at $100 \mu \mathrm{g} \mathrm{ml}^{-1}$, and rose Bengal at $30 \mu \mathrm{g} \mathrm{ml}^{-1}$. Pythium spp. growth on the surface of the selective medium was transferred to $1.7 \%$ CMA without antibiotics. Pure cultures were obtained by isolating hyphal tips followed by transfer to $1.7 \%$ CMA slants (4).

Identification to the species level was done using morphological characteristics (27) and sequences of the internal transcribed spacer (ITS) region of the ribosomal DNA (rDNA). In total, 59 randomly selected isolates of Pythium from 2006 and 33 from 2011 were sequenced and genotyped. Extraction of DNA from Pythium spp. was done following a modified protocol of Lee and Taylor (21) as explained by Al-Sa'di et al. (4). Polymerase chain reaction (PCR) mixtures and conditions were as per Al-Sadi et al. (2) using primers ITS1 and ITS4 (39). PCR products were purified using the QIAquick PCR purification kit (Qiagen, Germany) according to the manufacturer's protocol. Samples were sequenced by Macrogen (Korea) using primers ITS1 and ITS4.

The forward and backward ITS sequences for each isolate were first aligned and edited using ChromasPro (Technelysium Pty Ltd., Australia). The resulting ITS sequence for each isolate was then compared with sequences deposited at the National Center for Biotechnology Information using BLAST search. Sequences from this study and from GenBank were aligned using Clustal W (36). A neighbor-joining tree was constructed based on the matrix of pairwise distances obtained using the Kimura 2 parameter evolutionary model (Mega 5) (35). Bootstrap 50\% majority-rule consensus trees were generated using 1,000 replications.

Aggressiveness of $\boldsymbol{P}$. aphanidermatum isolates. The $92 P$. aphanidermatum isolates were tested for aggressiveness on 7-dayold cucumber seedlings as explained by Al-Sa'di et al. (4). Seedlings were raised in sterile potting mix in $15-\mathrm{cm}$-diameter plastic pots, with five seedlings per pot. The potting mix was sterilized at $121^{\circ} \mathrm{C}$ for $30 \mathrm{~min}$ over two consecutive days. A 6-mm mycelial plug obtained from a 3-day-old culture of Pythium grown on 3\% potato dextrose agar (Oxoid) was placed on the soil surface adjacent to each seedling using five replicate pots for each isolate. Pots were incubated at $27^{\circ} \mathrm{C}$ for 5 days following inoculation. The percentage of seedlings showing damping-off symptoms was recorded after 5 days. The experiment was repeated at least once for each isolate.

Metalaxyl sensitivity of $P$. aphanidermatum isolates. The degree of sensitivity of $P$. aphanidermatum isolates to metalaxyl was evaluated as in Al-Sa'di et al. (5). CMA (1.7\%) was amended with metalaxyl using five different concentrations $(0,0.1,0.5,1$, and 5 $\mu \mathrm{g} \mathrm{ml} \mathrm{m}^{-1}$ ). A 6-mm mycelia plug from a 3-day-old culture of each Pythium isolate was transferred to the edge of each petri dish. Four replicate petri dishes were used for each treatment and petri dishes were incubated at $25^{\circ} \mathrm{C}$. Linear growth was measured after 24,48 , 72 , and $96 \mathrm{~h}$. Metalaxyl concentration resulting in 50\% growth inhibition $\left(\mathrm{EC}_{50}\right)$ of Pythium was estimated from the fitted regression line of the percent inhibition plotted against log-transformed $\mathrm{EC}_{50}$. The experiment was repeated at least once for each isolate.

Amplified fragment length polymorphism fingerprinting of P. aphanidermatum. Amplified fragment length polymorphism (AFLP) was used to examine genetic diversity of $P$. aphanidermatum populations as well as genetic differentiation of $P$. aphanidermatum populations obtained from 2006 and 2011. In total, 92 different isolates (59 from 2006 and 33 from 2011) were included in the study. The AFLP protocol was modified from Vos et al. (37) as described by Al-Sa'di et al. (5) using FAM-6-labeled EcoRI primers. AFLP fingerprinting was first performed on a random sample of eight $P$. aphanidermatum isolates using 12 selective primer pair combinations. Of these, four highly polymorphic primer combinations $(\mathrm{E}+\mathrm{AAC} / \mathrm{M}+\mathrm{CG}, \mathrm{E}+\mathrm{AGA} / \mathrm{M}+\mathrm{CAG}$, $\mathrm{E}+\mathrm{AGA} / \mathrm{M}+\mathrm{CAT}$, and $\mathrm{E}+\mathrm{AG} / \mathrm{M}+\mathrm{CT})$ were selected.

DNA, extracted in the previous step, was digested for $90 \mathrm{~min}$ at $37^{\circ} \mathrm{C}$ using EcoRI (NEB, Frankfurt, Germany) and MseI (NEB) enzymes. This was followed by ligation reaction using EcoRI adaptor (5'-CTCGTAGACTGCGTACC/AATTGGTACGCAGTC$\left.3^{\prime}\right)$ and $M s e I$ adaptor (5'-TACTCAGGACTCAT/GACGATGAG TCCTGAG- $3^{\prime}$ ) at $37^{\circ} \mathrm{C}$ for $90 \mathrm{~min}$. Preselective and selective amplification reaction mixtures and PCR conditions were as described by Al-Sadi et al. (5) except for the use of PuReTaq ReadyTo-Go PCR beads (HVD Life Sciences, Vienna). Fragment analysis was carried out using ABI 3130 (Applied Biosystems, Carlsbad, CA).

Analysis of AFLP data. AFLP binary data, with 0 indicating absence and 1 indicating presence of each band of 50 to $500 \mathrm{bp}$, were used in the genetic analysis of $P$. aphanidermatum populations. POPGENE (v 1.32) (40) was used to determine Nei's (25) gene diversity and percentage of polymorphic loci within populations as well as genetic distance among isolates of $P$. aphanidermatum (26). This was followed by construction of a dendrogram using unweighted pair group method with arithmetic means (UPGMA; NTSYSpc v $2.21 \mathrm{~m}$ ) (28). Stoddart and Taylor (34) genotypic diversity $(\hat{\mathrm{G}})$ within each population was also determined $(15)$.

Partitioning of genetic variation among and within populations was conducted using analysis of molecular variance (AMOVA; Arlequin v. 3.1) (12). Total genetic variance was partitioned among and within populations based on planting rows from which the isolates were collected as well as years of isolation (2006 and 2011). Gene flow was estimated from the genetic differentiation $\left(\mathrm{F}_{\mathrm{ST}}\right)$ values according to McDermott and McDonald (23). In order to determine the level of clonality in populations of $P$. aphanidermatum, the index of association $\left(I_{\mathrm{A}}\right)$ and its significance levels under the null hypothesis of complete panmixis were determined using MultiLocus software (v. 1.2) based on 1,000 randomizations.

Analysis of aggressiveness and metalaxyl sensitivity data. Data generated from aggressiveness and metalaxyl sensitivity tests were analyzed using the Statistical Analysis System (SAS). Means were separated using Tukey's Studentized Range test. The Kolmogorov-Smirnov two-sample test was used to examine differences in the frequency distribution of the metalaxyl sensitivity and aggressiveness values between different populations.

\section{Results}

Isolation and identification of $\boldsymbol{P}$. aphanidermatum. Isolation from the 375 soil samples in 2006 using Pythium spp.-selective 
medium yielded 101 Pythium isolates (isolation frequency $=27 \%$ ). Isolations in 2011 from 90 randomly selected soil samples using the same medium yielded 85 Pythium isolates (94\%).

Amplification and sequencing of 59 randomly selected isolates from 2006 and 33 randomly selected isolates from 2011 using ITS1 and ITS4 primers produced a fragment of DNA which was $777 \mathrm{bp}$ in length for all isolates, except one isolate with a 778-bp fragment. All isolates shared identical sequence with a previously deposited ITS sequence of a $P$. aphanidermatum isolate (P002; DQ298521) from Oman, except for a 1-bp mismatch for isolate A1-2 from 2006. This confirmed the identity of all isolates as $P$. aphanidermatum.

Aggressiveness of $\boldsymbol{P}$. aphanidermatum isolates. Significant differences were found in aggressiveness among different $P$. aphanidermatum isolates obtained from the same year $(P<0.05)$. Most (89\%) P. aphanidermatum isolates from the 2 years were found to cause over $50 \%$ mortality of cucumber seedlings. However, no significant differences were observed in the aggressiveness level among populations of $P$. aphanidermatum obtained from different planting rows within the same year (Table 1 and 2). P. aphanidermatum populations from 2011 were as aggressive as populations from 2006 (Fig. 1; Table 2). The 2006 isolates of $P$. aphanidermatum caused 6 to $100 \%$ (average 68\%) mortality in cucumber while the 2011 isolates caused 4 to $96 \%$ (average $73 \%$ ) mortality.

Metalaxyl sensitivity of $\boldsymbol{P}$. aphanidermatum isolates. Isolates of $P$. aphanidermatum exhibited significant differences in sensitivity to metalaxyl $(P<0.05)$. The $\mathrm{EC}_{50}$ values for the different isolates were 0.002 to 1.823 (average $0.632 \mu \mathrm{g} \mathrm{ml} \mathrm{g}^{-1}$ ). Most $(83 \%$ ) isolates of $P$. aphanidermatum were found to have $\mathrm{EC}_{50}$ values of less than $1 \mu \mathrm{g} \mathrm{ml}{ }^{-1}$.

Populations of $P$. aphanidermatum obtained from different planting rows within the same year were found to have similar levels of sensitivity to metalaxyl, except for the population obtained from planting row 5 in 2006 (Table 1). However, the 2011 population (average $\mathrm{EC}_{50}=0.160 \mu \mathrm{g} \mathrm{ml}^{-1}$ ) was more sensitive to metalaxyl than the 2006 population (average $\mathrm{EC}_{50}=0.824 \mu \mathrm{g} \mathrm{ml}^{-1}$ ) (Table 2). In addition, the Kolmogorov-Smirnov two-sample test

Table 1. Aggressiveness and metalaxyl sensitivity levels of Pythium aphanidermatum populations obtained from different planting rows in 2006 and $2011^{\mathrm{y}}$

\begin{tabular}{|c|c|c|c|c|}
\hline \multirow[b]{2}{*}{ Population, row } & \multicolumn{2}{|c|}{ Aggressiveness } & \multicolumn{2}{|c|}{ Metalaxyl sensitivity } \\
\hline & $\begin{array}{c}\text { Sample } \\
\text { size }\end{array}$ & $\begin{array}{c}\text { Mean } \\
\text { (\% } \text { mortality) }\end{array}$ & $\begin{array}{c}\text { Sample } \\
\text { size }\end{array}$ & $\begin{array}{l}\text { Mean } \\
\left(\mathbf{E C}_{50}\right)^{\mathrm{z}}\end{array}$ \\
\hline \multicolumn{5}{|l|}{2006} \\
\hline 1 & 5 & $78 \mathrm{a}$ & 5 & $0.735 b$ \\
\hline 2 & 8 & $53 \mathrm{a}$ & 10 & $0.813 b$ \\
\hline 3 & 9 & $69 \mathrm{a}$ & 11 & $0.789 \mathrm{~b}$ \\
\hline 4 & 27 & $70 \mathrm{a}$ & 29 & $0.790 \mathrm{~b}$ \\
\hline 5 & 3 & $71 \mathrm{a}$ & 4 & $1.300 \mathrm{a}$ \\
\hline \multicolumn{5}{|l|}{2011} \\
\hline 1 & 11 & $72 \mathrm{a}$ & 11 & $0.110 \mathrm{a}$ \\
\hline 3 & 3 & $49 \mathrm{a}$ & 1 & $\ldots$ \\
\hline 5 & 7 & $78 \mathrm{a}$ & 6 & $0.259 \mathrm{a}$ \\
\hline 6 & 7 & $81 \mathrm{a}$ & 7 & $0.136 \mathrm{a}$ \\
\hline
\end{tabular}

${ }^{y}$ Values with the same letter in the same year and column are not significantly different from each other at $P<0.05$ (Tukey's Studentized Range test, SAS).

${ }^{\mathrm{z}}$ Concentration resulting in 50\% growth inhibition. indicated that the frequency distribution of $P$. aphanidermatum isolates based on the $\mathrm{EC}_{50}$ values was significantly different between the 2 years $(P=0.031$; Fig. 2$)$. The population of $P$. aphanidermatum from 2011 was found to have a narrow range of metalaxyl sensitivity ( 0.002 to 0.564 , average $0.160 \mu \mathrm{g} \mathrm{ml}^{-1}$; standard deviation $[\mathrm{SD}]=0.148$ ) compared with the 2006 population $\left(0.070\right.$ to 1.823 , average $0.824 \mu \mathrm{g} \mathrm{ml}^{-1}$; $\left.\mathrm{SD}=0.300\right)$.

Genotypic and genetic diversity within populations of $\boldsymbol{P}$. aphanidermatum. Analysis of 92 isolates of $P$. aphanidermatum using four primer combinations produced 92 different genotypes and 985 polymorphic loci. All populations of $P$. aphanidermatum in 2006 and 2011 were found to have low levels of genetic diversity $(H=0.0946$ to 0.1499 ; overall 0.1425$)$. Genetic diversity of $P$. aphanidermatum populations from $2006(H=0.1405)$ was comparable with that in $2011(H=0.1257)$. Little variation was detected in the genetic diversity of $P$. aphanidermatum populations obtained from the different planting rows within the same year (Table 3). No unique alleles were detected in any of the populations in 2006 or 2011.

Genetic distance and cluster analysis. Analysis of genetic distance showed that the genetic distance among all isolates of $P$. aphanidermatum was 0.064 to 0.489 (average 0.217) (Fig. 3). The genetic distances among isolates within 2006 and 2011 were 0.064 to 0.461 (average 0.196 ) and 0.075 to 0.455 (average 0.199), respectively.

The genetic distance between populations obtained from the different rows within the 2006 and 2011 populations were 0.004 to 0.019 (average 0.010 ) and 0.004 to 0.034 (average 0.017 ), respectively.

UPGMA analysis based on the genetic distance among isolates showed separation of most of the 2006 isolates from the 2011 isolates in different clusters (Fig. 3). Many of the clusters were sup-

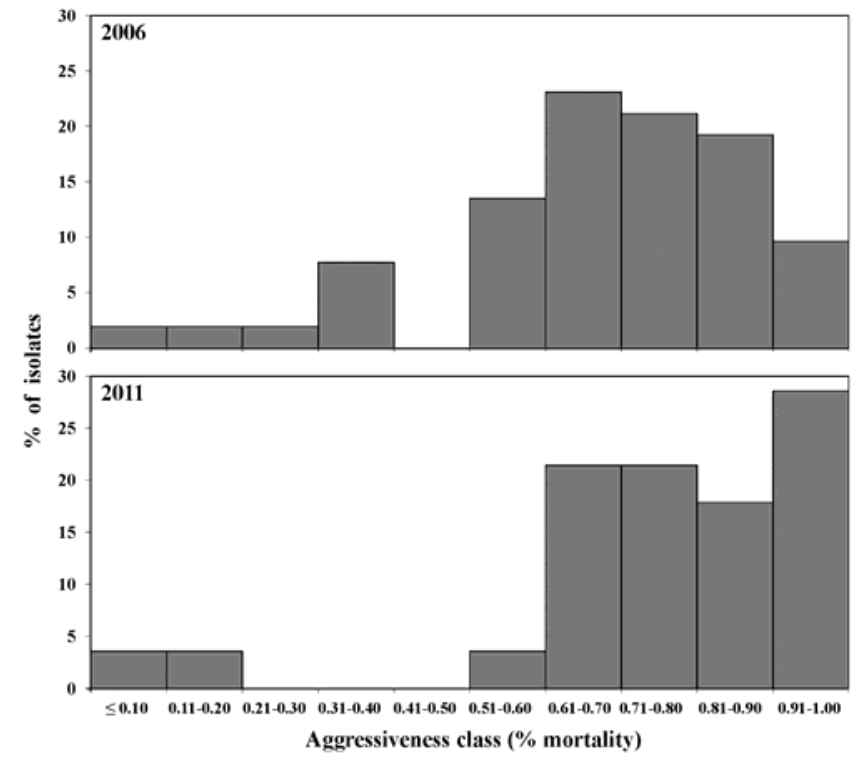

Fig. 1. Distribution of aggressiveness levels for Pythium aphanidermatum isolates obtained in $2006(n=52)$ and $2011(n=28)$. No significant differences were found in frequency distribution of aggressiveness levels between the populations from 2006 and 2011 ( $P=0.975$; Kolmogorov-Smirnov two-sample test).

Table 2. Change in the aggressiveness and metalaxyl sensitivity levels of Pythium aphanidermatum populations between 2006 and $2011^{\mathrm{y}}$

\begin{tabular}{|c|c|c|c|c|c|c|c|}
\hline \multirow[b]{2}{*}{ Year } & \multicolumn{3}{|c|}{ Metalaxyl sensitivity $\left(\mathbf{E C}_{50}\right)^{\mathrm{z}}$} & \multicolumn{4}{|c|}{ Aggressiveness levels (\% mortality) } \\
\hline & Row 1 & Row 5 & Overall & Row 1 & Row 3 & Row 5 & Overall \\
\hline$\overline{2006}$ & $0.735 \mathrm{a}$ & $1.300 \mathrm{a}$ & $0.824 \mathrm{a}$ & $78 \mathrm{a}$ & $69 \mathrm{a}$ & $71 \mathrm{a}$ & $68 \mathrm{a}$ \\
\hline 2011 & $0.110 \mathrm{~b}$ & $0.259 \mathrm{~b}$ & $0.160 \mathrm{~b}$ & $72 \mathrm{a}$ & $49 \mathrm{a}$ & $78 \mathrm{a}$ & $73 \mathrm{a}$ \\
\hline
\end{tabular}

y Values with the same letter in the same column are not significantly different from each other at $P<0.05$ (Tukey's Studentized Range test, SAS).

${ }^{\mathrm{z}}$ Concentration resulting in $50 \%$ growth inhibition. 
ported with high bootstrap support levels. However, some of the clusters which were supported with a high bootstrap value also consisted of isolates from 2006 and 2011 as well as of isolates from different planting rows within the same year (Fig. 3). Clustering was not related to metalaxyl sensitivity levels or aggressiveness levels (Fig. 3). No relationship was found between metalaxyl sensitivity of isolates and their aggressiveness levels $(P=0.9596)$.

Partitioning of genetic variation in $P$. aphanidermatum. AMOVA analysis indicated the presence of very low levels of genetic differentiation among populations of $P$. aphanidermatum obtained from different planting rows within the same year. The $\mathrm{F}_{\mathrm{ST}}$ values were -0.0295 to 0.0983 (average 0.0307 ) in 2006 and -0.0079 to 0.0720 (average 0.0222) in 2011 (Tables 4, 5, and 6). Most of the genetic variation was found to be within the populations obtained from rows rather than being among the different rows. This resulted in a high level of gene flow among the different planting rows (7.9 in 2006 and 11.0 in 2011; Table 6). However, AMOVA analysis indicated the existence of a moderate level of genetic differentiation $\left(\mathrm{F}_{\mathrm{ST}}=0.1731\right)$ among the 2006 and the 2011 population.

The $I_{\mathrm{A}}$ values for the 2006 and the 2011 populations were $19.6175(P<0.001)$ and $19.1227(P<0.001)$, respectively (Table $7)$. Both values deviated significantly from the null hypothesis of complete panmixis in the populations.

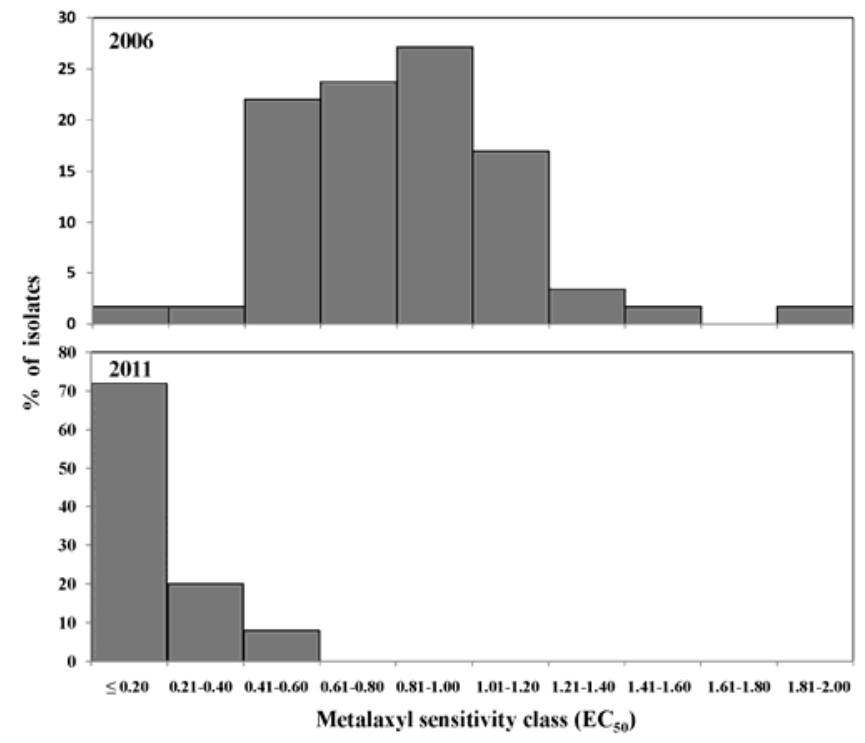

Fig. 2. Distribution of metalaxyl sensitivity levels for Pythium aphanidermatum isolates obtained in $2006(n=59)$ and $2011(n=25)$. Significant differences were found in frequency distribution of metalaxyl sensitivity levels between the populations from 2006 and 2011 ( $P=0.031$; Kolmogorov-Smirnov two-sample test).

\section{Discussion}

Isolations from the greenhouse in 2006 revealed that about $27 \%$ of the planting sites for cucumber seedlings were contaminated with $P$. aphanidermatum inoculum. Although the greenhouse was only established in 2005, the relatively moderate levels of soil contamination after 1 year could be due to establishment of the greenhouse on farm soil which had previously been used for vegetable production (farmer, personal communication). Previous studies have emphasized the role of cultivation soil as a main source of Pythium inoculum $(7,30)$. However, the increase in contaminated planting sites from $27 \%$ in 2006 to $94 \%$ in 2011 could be related, in part, to the buildup of inoculum in the greenhouse via multiplication of the pathogen as well as to the introduction of new $P y$ thium inoculum into the greenhouse via potting media, machinery, or workers (7). The dominance of $P$. aphanidermatum in this greenhouse supports previous studies indicating the wide distribution of this pathogen in Oman $(3,4)$. The present study also confirms previous reports of limited intraspecific variation in the ITS sequence of $P$. aphanidermatum $(4,22)$.

$P$. aphanidermatum isolates from 2006 and 2011 were found to have high levels of aggressiveness to cucumber seedlings. However, no significant differences were observed in aggressiveness among populations of $P$. aphanidermatum within the same year or among populations from the 2 years. Findings from this study together with previous reports indicate the high aggressiveness of $P$. aphanidermatum on cucumber and the limited variation in aggressiveness among populations from different origins or hosts $(4,5)$. This may suggest that the aggressiveness test for this pathogen is not a good parameter for differentiating populations from different origins.

Examining sensitivity of $P$. aphanidermatum isolates to metalaxyl showed that all isolates were sensitive. However, the 2011 population $\left(\mathrm{EC}_{50}=0.002\right.$ to 0.564 , average $0.160 \mu \mathrm{g} \mathrm{ml}^{-1}$ ) was found to be significantly more sensitive to metalaxyl than the 2006 population $\left(\mathrm{EC}_{50}=0.070\right.$ to 1.823 , average $\left.0.824 \mu \mathrm{g} \mathrm{m}{ }^{-1}\right)$. This was evident from differences in the average $\mathrm{EC}_{50}$ level and from the frequency distributions of metalaxyl sensitivity levels of the two populations. The increase in sensitivity of $P$. aphanidermatum isolates to metalaxyl following 26 applications of the fungicide between 2006 and 2011 is somewhat surprising because it is known that frequent application of metalaxyl can select for resistance in a population $(29,32,38)$. There are two alternative explanations for what had happened in this greenhouse. First, the lesssensitive isolates could also have reduced fitness in the greenhouse; a bottlenecking phenomenon could have resulted in eliminating the less-fit isolates from the greenhouse. However, populations from the 2 years were equally aggressive on cucumber $(P=0.9596)$. This implies that competition between the more-sensitive and the less-sensitive isolates was not evident as a factor responsible for

Table 3. Population genetic analysis of Pythium aphanidermatum in 2006 and $2011^{\mathrm{z}}$

\begin{tabular}{|c|c|c|c|c|c|c|c|}
\hline Population, subpopulation & $\mathbf{N}$ & NPL & PPL (\%) & NUA & g & G/g (\%) & $\mathbf{H}$ \\
\hline \multicolumn{8}{|l|}{2006} \\
\hline Row 1 & 5 & 378 & 38.4 & 0 & 5 & 100 & 0.1153 \\
\hline Row 2 & 10 & 627 & 63.7 & 0 & 10 & 100 & 0.1499 \\
\hline Row 3 & 11 & 612 & 62.1 & 0 & 11 & 100 & 0.1392 \\
\hline Row 4 & 29 & 682 & 69.2 & 0 & 29 & 100 & 0.1243 \\
\hline Row 5 & 4 & 333 & 33.8 & 0 & 4 & 100 & 0.1106 \\
\hline Overall & 59 & 895 & 90.9 & 0 & 59 & 100 & 0.1405 \\
\hline \multicolumn{8}{|l|}{2011} \\
\hline Row 1 & 16 & 644 & 65.4 & 0 & 16 & 100 & 0.1192 \\
\hline Row 3 & 5 & 483 & 49.0 & 0 & 5 & 100 & 0.1395 \\
\hline Row 5 & 7 & 362 & 36.8 & 0 & 7 & 100 & 0.0946 \\
\hline Row 6 & 5 & 357 & 36.2 & 0 & 5 & 100 & 0.1068 \\
\hline Overall & 33 & 806 & 81.8 & 0 & 33 & 100 & 0.1257 \\
\hline Overall & 92 & 985 & 100 & $\ldots$ & 92 & 100 & 0.1425 \\
\hline
\end{tabular}

${ }^{\mathrm{z}} \mathrm{N}$ is the sample size, NPL is the number of polymorphic loci, PPL is the percentage of polymorphic loci, NUA is the number of unique alleles, $\mathrm{g}$ is the number of different genotypes recovered, G/g (\%) is the percentage of maximum diversity in each population (15), and $\mathrm{H}$ is Nei's (25) gene diversity. 


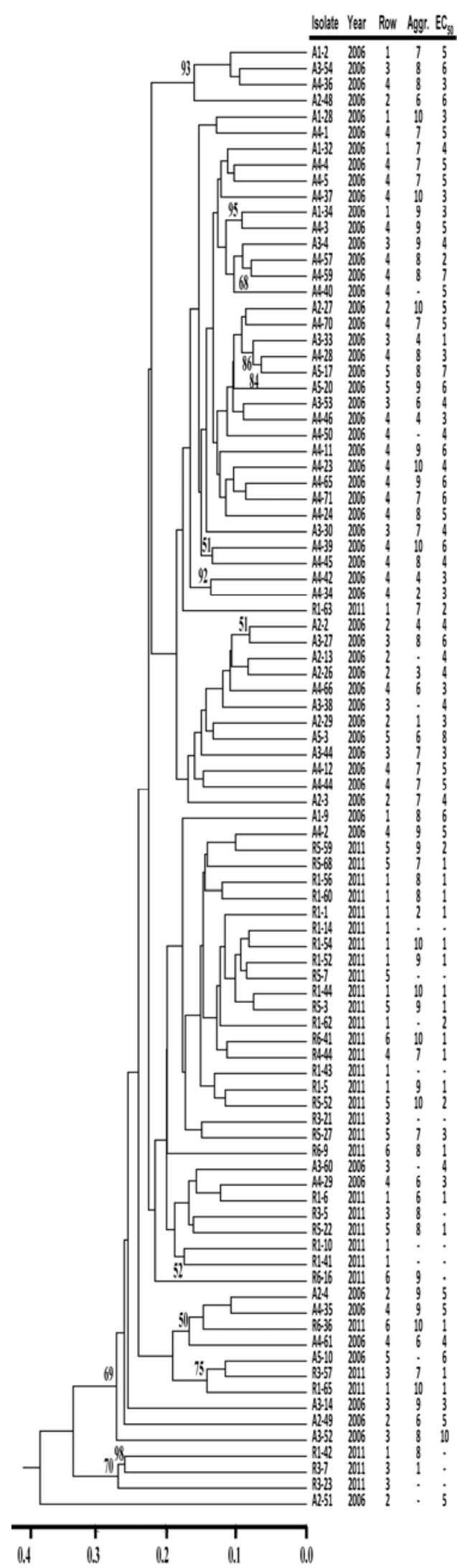

Fig. 3. Unweighted pair group method with arithmetic means dendrogram showing Nei's (26) genetic distances of 92 isolates of Pythium aphanidermatum obtained from a single greenhouse in 2006 and 2011 based on amplified fragment length polymorphism fingerprinting analysis using 985 polymorphic alleles. Numbers within the tree represent the bootstrap values (values above $50 \%$ are indicated; 1,000 replications). Columns from left to right indicate isolate accession number, year of isolation, planting row, aggressiveness class and metalaxyl sensitivity class. Missing values are indicated as ".". eliminating the less-sensitive isolates from the greenhouse. However, whether the degree of fitness of the different isolates in the greenhouse is associated with certain environmental conditions, soil characteristics, or biological interactions is a question that deserves investigations in future studies.

A second explanation for the shift in metalaxyl sensitivity is that most of the isolates from 2006 were replaced by new isolates over subsequent years. The farmer used to leave the greenhouse fallow for up to 40 days in the summer, during which the temperature inside the greenhouse in Oman can reach 50 to $60^{\circ} \mathrm{C}$. This could have resulted in eliminating most of the zoospores and mycelium and many of the oospores of Pythium from the soil $(10,11)$. At the same time, new $P$. aphanidermatum inoculum with high sensitivity to metalaxyl could have been introduced into the greenhouse over the subsequent years via different sources $(2,7)$. This hypothesis is supported by genetic analysis which indicated clustering of many of the 2006 and 2011 isolates in separate clusters as well as by the moderate levels of genetic differentiation $\left(\mathrm{F}_{\mathrm{ST}}\right)$ which were observed between populations from the 2 years.

Examining genetic diversity of $P$. aphanidermatum from a single greenhouse showed that $P$. aphanidermatum populations from 2006 and 2011 had low levels of genetic diversity $(H=0.1425)$. These are comparable with previously reported levels of genetic diversity of $P$. aphanidermatum in greenhouses in Oman (5). However, these are low compared with the reports for $P$. aphanidermatum in greenhouses in Pennsylvania $(H=0.34)(20)$. This could be related to a more frequent rate of Pythium spp. introduction into greenhouses in Pennsylvania via imported planting material, a practice not frequent for Pythium spp. in Oman (7). Additionally, all isolates in this study were obtained from a single greenhouse, in which populations could have been introduced via common sources. This is supported by the lack of unique alleles in any of the populations examined. The limited change in the genetic diversity of $P$. aphanidermatum from 2006 (0.14050) to 2011 (0.1257) could be attributed to elimination of much of the 2006 inoculum from the greenhouse by cultural practices (fallow greenhouses in summer) or introduction of new inoculum via common sources.

The $I_{\mathrm{A}}$ values indicate that populations of $P$. aphanidermatum in 2006 and 2011 were reproducing asexually, or mainly via selfing. This is in agreement with the homothallic nature of this pathogen (27) and could have resulted in lower levels of genetic diversity when compared with Pythium populations that reproduce by crossing $(16,17)$.

AMOVA analysis indicated the presence of low levels of genetic differentiation among populations of $P$. aphanidermatum obtained from different planting rows within the same year. This indicates a high level of gene flow among rows in the greenhouse as a result of soil mixing between different planting rows at the time of soil preparation by farmers. This could result in dispersal of $P$. aphanidermatum from one place in the greenhouse to another, causing nonrandom distribution of the pathogen in the greenhouse.

No relationship was found between clustering of isolates and their aggressiveness or metalaxyl sensitivity. This is in agreement with previous findings $(1,5)$. However, Lee at al. (20) reported a relationship between clustering of $P$. aphanidermatum isolates and their resistance to mefenoxam. This may be related to the fact that the isolates used by Lee et al. (20) included resistant and sensitive types; all of the isolates from Oman were sensitive to metalaxyl.

The present study provides evidence for a change in the population structure of $P$. aphanidermatum from a single greenhouse over time which could be partially attributed to the elimination of previous inoculum by summer heat and introduction of new inoculum via common sources. Although the elimination of inoculum from the greenhouse benefits the farmer, reintroduction of new inoculum into the greenhouse is an issue which needs to be tackled through management programs. Due to the lack of adequate knowledge about factors which could have influenced the change in the population structure of $P$. aphanidermatum during 2006 to 2011, this is an issue which deserves further investigations. Additionally, future studies may consider evaluating the fitness of $P$. aphanider- 
Table 4. Pairwise genetic differentiation among populations of Pythium aphanidermatum obtained from different planting rows in $2006^{\mathrm{Z}}$

\begin{tabular}{|c|c|c|c|c|c|c|}
\hline Population & Sample size & Row 1 & Row 2 & Row 3 & Row 4 & Row 5 \\
\hline Row 1 & 5 & & 0.04505 & 0.9009 & 0.63964 & 0.28829 \\
\hline Row 2 & 10 & 0.06088 & $\ldots$ & 0.10811 & $<0.0001$ & 0.27928 \\
\hline Row 3 & 11 & -0.02946 & 0.01466 & $\ldots$ & 0.023423 & 0.69369 \\
\hline Row 4 & 27 & -0.00723 & 0.09829 & 0.00528 & $\ldots$ & 0.07207 \\
\hline Row 5 & 4 & 0.01289 & 0.0172 & -0.0276 & 0.02555 & $\ldots$ \\
\hline
\end{tabular}

${ }^{\mathrm{z}}$ Below diagonal, genetic differentiation $\left(\mathrm{F}_{\mathrm{ST}}\right)$ value; above diagonal, probabilities of having more extreme $\mathrm{F}_{\mathrm{ST}}$ value than observed.

Table 5. Pairwise genetic differentiation among populations of Pythium aphanidermatum obtained from different planting rows in $2011^{\mathrm{z}}$

\begin{tabular}{lcccc}
\hline Population & Sample size & Row 1 & Row 3 & Row 5 \\
\hline Row 1 & 16 & $\ldots$ & 0.07207 & 0.64865 \\
Row 3 & 5 & 0.04938 & $\ldots$ & 0.05405 \\
Row 5 & 7 & -0.00790 & 0.07203 & $\ldots$ \\
Row 6 & 5 & 0.01137 & 0.02979 & 0.25225 \\
\hline
\end{tabular}

${ }^{\mathrm{z}}$ Below diagonal, genetic differentiation $\left(\mathrm{F}_{\mathrm{ST}}\right)$ value; above diagonal, probabilities of having more extreme $\mathrm{F}_{\mathrm{ST}}$ value than observed.

Table 6. Measured variation among and within populations of Pythium aphanidermatum using analysis of molecular variance

\begin{tabular}{|c|c|c|c|c|c|c|c|}
\hline Source of variation & Df & Sum of squares & Variance component & Variation (\%) & $\mathbf{F}_{\mathbf{S T}}{ }^{\mathbf{z}}$ & $\boldsymbol{P}$ & Gene flow \\
\hline \multicolumn{8}{|l|}{2006 Population } \\
\hline Among & 4 & 447.466 & 2.68509 & 3.07 & 0.03069 & 0.00587 & 7.9 \\
\hline Within & 54 & $4,579.788$ & 84.81089 & 96.93 & $\ldots$ & $\ldots$ & $\ldots$ \\
\hline \multicolumn{8}{|l|}{2011 Population } \\
\hline Among & 3 & 301.859 & 1.95375 & 2.22 & 0.02218 & 0.09091 & 11.02 \\
\hline Within & 29 & $2,497.898$ & 86.13442 & 97.78 & $\ldots$ & $\ldots$ & $\ldots$ \\
\hline \multicolumn{8}{|l|}{2006 and 2011} \\
\hline Among & 1 & 857.445 & 18.20338 & 17.31 & 0.17309 & $<0.00001$ & 1.19 \\
\hline Within & 90 & $7,827.012$ & 86.9668 & 82.69 & $\ldots$ & $\ldots$ & $\ldots$ \\
\hline
\end{tabular}

${ }^{\mathrm{z}}$ Genetic differentiation.

Table 7. Index of association $\left(I_{\mathrm{A}}\right)$ values for populations of Pythium aphanidermatum in 2006 and 2011

\begin{tabular}{lcc}
\hline Population & $\boldsymbol{I}_{\mathbf{A}}$ & Probability \\
\hline 2006 & 19.6175 & $<0.0100000$ \\
2011 & 19.1227 & $<0.0100000$ \\
\hline
\end{tabular}

matum populations from Oman having differential sensitivities to metalaxyl.

\section{Acknowledgments}

We thank Sultan Qaboos University for financial support for this study through His Majesty's Strategic Research Fund (Potential sources of plant pathogenic fungi and bacteria into farms in Oman, SR/AGR/CROP/10/01), an anonymous farmer for help in the collection of soil samples and data, and I. AlMahmooli for technical help.

\section{Literature Cited}

1. Al-Sadi, A. M., Al-Masoudi, R. S., Al-Habsi, N., Al-Said, F. A., Al-Rawahy, S. A., Ahmed, M., and Deadman, M. L. 2010. Effect of salinity on Pythium damping-off of cucumber and on the tolerance of Pythium aphanidermatum. Plant Pathol. 59:112-120.

2. Al-Sadi, A. M., Al-Said, F. A., Al-Jabri, A. H., Al-Mahmooli, I. H., Al-Hinai, A. H., and de Cock, A. W. A. M. 2011. Occurrence and characterization of fungi and oomycetes transmitted via potting mixtures and organic manures. Crop Prot. 30:38-44.

3. Al-Sadi, A. M., Al-Said, F. A., Al-Kiyumi, K. S., Al-Mahrouqi, R. S., AlMahmooli, I. H., and Deadman, M. L. 2011. Etiology and characterization of cucumber vine decline in Oman. Crop Prot. 30:192-197.

4. Al-Sa'di, A. M., Drenth, A., Deadman, M., de Cock, A. W. A. M., and Aitken, E. A. B. 2007. Molecular characterization and pathogenicity of Pythium species associated with damping-off in greenhouse cucumber ( $\mathrm{Cucu}$ mis sativus L.) in Oman. Plant Pathol. 56:140-149.

5. Al-Sa'di, A. M., Drenth, A., Deadman, M. L., and Aitken, E. A. B. 2008. Genetic diversity, aggressiveness and metalaxyl sensitivity of Pythium aphanidermatum populations infecting cucumber in Oman. Plant Pathol. 57:45-56.

6. Al-Sa'di, A. M., Drenth, A., Deadman, M. L., Al-Said, F. A., Khan, I., and Aitken, E. A. B. 2008. Association of a second phase of mortality in cucumber seedlings with a rapid rate of metalaxyl biodegradation in greenhouse soils. Crop Prot. 27:1110-1117.
7. Al-Sa'di, A. M., Drenth, A., Deadman, M. L., Al-Said, F. A., Khan, I., and Aitken, E. A. B. 2008. Potential sources of Pythium inoculum into greenhouse soils with no previous history of cultivation. J. Phytopathol. 156:502505.

8. Al-Sa'di, A. M., Drenth, A., Deadman, M. L., de Cock, A. W. A. M., AlSaid, F. A., and Aitken, E. A. B. 2008. Genetic diversity, aggressiveness and metalaxyl sensitivity of Pythium spinosum infecting cucumber in Oman. J. Phytopathol. 156:29-35.

9. Brantner, J. R., and Windels, C. E. 1998. Variability in sensitivity to metalaxyl in vitro, pathogenicity, and control of Pythium spp. on sugar beet. Plant Dis. 82:896-899.

10. Christensen, L. K., and Thinggaard, K. 1999. Solarization of greenhouse soil for prevention of Pythium root rot in organically grown cucumber. J. Plant Pathol. 81:137-144.

11. Deadman, M., Al-Hasani, H., and Al-Sa'di, A. M. 2006. Solarization and biofumigation reduce Pythium aphanidermatum induced damping-off and enhance vegetative growth of greenhouse cucumber in Oman. J. Plant Pathol. 88:333-335.

12. Excoffier, L., Laval, G., and Schneider, S. 2005. Arlequin (version 3.0): an integrated software package for population genetics data analysis. Evol. Bioinf. Online 1:47-50.

13. FAO. 2011. FAOSTAT-Agriculture. http://faostat.fao.org/site/567/default. aspx\#ancor.

14. Garzon, C. D., Geiser, D. M., and Moorman, G. W. 2005. Diagnosis and population analysis of Pythium species using AFLP fingerprinting. Plant Dis. 89:81-89.

15. Grünwald, N. J., Goodwin, S. B., Milgroom, M. G., and Fry, W. E. 2003 Analysis of genotypic diversity data for populations of microorganisms. Phytopathology 93:738-746.

16. Harvey, P. R., Butterworth, P. J., Hawke, B. G., and Pankhurst, C. E. 2000. Genetic variation among populations of Pythium irregulare in southern Australia. Plant Pathol. 49:619-627.

17. Harvey, P. R., Butterworth, P. J., Hawke, B. G., and Pankhurst, C. E. 2001 Genetic and pathogenic variation among cereal, medic and sub-clover isolates of Pythium irregulare. Mycol. Res. 105:85-93.

18. Herrero, M. L., Hermansen, A., and Elen, O. N. 2003. Occurrence of Pythium spp. and Phytophthora spp. in Norwegian greenhouses and their pathogenicity on cucumber seedlings. J. Phytopathol. 151:36-41.

19. Jeffers, S. N., and Martin, S. B. 1986. Comparison of two media selective for Phytophthora and Pythium species. Plant Dis. 70:1038-1043.

20. Lee, S., Garzon, C. D., and Moorman, G. W. 2010. Genetic structure and distribution of Pythium aphanidermatum populations in Pennsylvania greenhouses based on analysis of AFLP and SSR markers. 
Mycologia 102:774-784.

21. Lee, S. B., and Taylor, J. W. 1990. Isolation of DNA from fungal mycelia and single spores. Pages 282-287 in: PCR Protocols: A Guide to Methods and Applications. M. A. Innis, D. H. Gelfand, J. J. Sninsky and T. J. White, eds. Academic Press, New York.

22. Lévesque, C. A., and de Cock, A. W. A. M. 2004. Molecular phylogeny and taxonomy of the genus Pythium. Mycol. Res. 108:1363-1383.

23. McDermott, J. M., and McDonald, B. A. 1993. Gene flow in plant pathosystems. Annu. Rev. Phytopathol. 31:353-373.

24. Moorman, G. W., and Kim, S. H. 2004. Species of Pythium from greenhouses in Pennsylvania exhibit resistance to propamocarb and mefenoxam. Plant Dis. 88:630-632.

25. Nei, M. 1973. Analysis of gene diversity in subdivided populations. Proc. Nat. Acad. Sci. USA 70:3321-3323.

26. Nei, M. 1978. Estimation of average heterozygosity and genetic distance from a small number of individuals. Genetics 89:583-590.

27. Plaats-Niterink, A. J. V.-d. 1981. Monograph of the genus Pythium. Stud. Mycol. 21:1-242.

28. Rohlf, F. J. 2009. NTSYSpc: Numerical Taxonomy System, ver. 2.21c. Exeter Software, Setauket, NY

29. Skylakakis, G. 1987. Changes in the composition of pathogen populations caused by resistance to fungicides. Pages 227-237 in: Populations of Plant Pathogens: Their Dynamics and Genetics. M. S. Wolfe and C. E. Caten, eds. Blackwell Scientific Publications, Oxford.

30. Stanghellini, M. E., and Nigh, E. L., Jr. 1972. Occurrence and survival of Pythium aphanidermatum under arid soil conditions in Arizona. Plant Dis. Rep. 56:507-510.

31. Stanghellini, M. E., and Phillips, J. M. 1975. Pythium aphanidermatum: its occurrence and control with pyroxychlor in the Arabian desert at Abu Dhabi. Plant Dis. Rep. 59:559-563.
32. Staub, T., and Sozzi, D. 1983. Recent practical experience with fungicide resistance. 10th International Congress of Plant Protection: Plant Protection for Human Welfare 2:591-598.

33. Stephens, C. T., Herr, L. J., Schmitthenner, A. F., and Powell, C. C. 1983. Sources of Rhizoctonia solani and Pythium spp. in a bedding plant greenhouse. Plant Dis. 67:272-275.

34. Stoddart, J. A., and Taylor, J. F. 1988. Genotypic diversity: estimation and prediction in samples. Genetics 118:705-711.

35. Tamura, K., Peterson, D., Peterson, N., Stecher, G., Nei, M., and Kumar, S MEGA5: Molecular Evolutionary Genetics Analysis using Maximum Likelihood, Evolutionary Distance, and Maximum Parsimony Methods. Mol. Biol. Evol. 28:2731-2739.

36. Thompson, J. D., Higgins, D. G., and Gibson, T. J. 1994. CLUSTAL W: improving the sensitivity of progressive multiple sequence alignment through sequence weighting, position-specific gap penalties and weight matrix choice. Nucleic Acids Res. 22:4673-4680.

37. Vos, P., Hogers, R., Bleeker, M., Reijans, M., van de Lee, T., Hornes, M. Frijters, A., Pot, J., Peleman, J., Kuiper, M., and Zabeau, M. 1995. AFLP: a new technique for DNA fingerprinting. Nucleic Acids Res. 23:4407-4414.

38. White, J. G., Stanghellini, M. E., and Ayoubi, L. M. 1988. Variation in the sensitivity of metalaxyl of Pythium spp. isolated from carrot and other sources. Ann. Appl. Biol. 113:269-277.

39. White, T. J., Bruns, T., Lee, S., and Taylor, J. 1990. Amplification and direct sequencing of fungal ribosomal RNA genes for phylogenetics. Pages 315322 in: PCR Protocols: A Guide to Methods and Applications. M. A. Innis, D. H. Gelfand, J. J. Sninsky and T. J. White, eds. Academic Press, New York

40. Yeh, R. C., and Boyle, T. J. B. 1997. Population genetic analysis of codominant and dominant markers and quantitative traits. Belg. J. Bot. 129:157. 